\title{
Histology of hematoxylin-eosin and immunohistochemical diabetes rat pancreas after giving combination of moringa leaves (Moringa oleifera) and clove flower (Syzygium aromaticum) extracts
}

\author{
Purnama Ningsih ${ }^{1 *}$, Sitti Rahmawati ${ }^{1}$, Baharuddin Hamzah ${ }^{1}$, Tri Santoso ${ }^{1}$, Nurbaya Nurbaya ${ }^{1}$, Muhammad Fakhrul Hardani ${ }^{2}$, \\ Ririen Hardani ${ }^{2}$
}

${ }^{1}$ Chemistry Study Program, Mathematics and Sciences Division, Faculty of Teacher Training and Education, Tadulako University, Palu, Indonesia; ${ }^{2}$ Department of Pharmacy, Faculty of Mathematics and Natural Sciences, Tadulako University, Palu, Indonesia

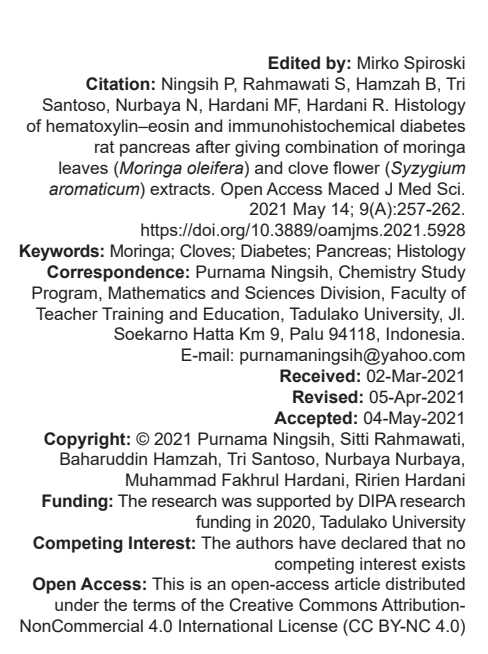

\begin{abstract}
AIM: The purpose of this study was to determine the regeneration activity of pancreatic beta cells by a combination of the ethanol extracts of moringa leaves and clove flower.

METHODS: This is experimental laboratory research using posttest only group design. The subject of this research is 40 white male rats of Wistar strain (Rattus norvegicus) and was conditioned diabetes mellitus by streptozotocinnicotinamide induction. The rats randomly divided into 8 groups, and each group consisted of 5 rats. Combination dose of moringa leaves and clove flower extracts used are 150:40 mg/kg body weight of mice, $100: 80 \mathrm{mg} / \mathrm{kg}$ body weight of mice, and $50: 120 \mathrm{mg} / \mathrm{kg}$ body weight of mice. The rats were sacrificed and the pancreas taken to be made preparations histopathology, staining, and observation tissues with hematoxylin-eosin (HE) and immunohistochemical $(\mathrm{IHC})$ methods.

RESULTS: The results showed that the staining and observation tissues of heart with HE method acquired the positive control group, the single test group and the combination group was showing the islet on the Langerhans Island of the pancreas is bigger than in the negative control group.

CONCLUSION: The morphology of the island of Langerhans increasingly large indicates increasing the regeneration of the cells of the islet beta pancreas, whereas the method of IHC acquired the negative control group seen lack of display intensity of positive reaction antigen $(\mathrm{Ag})$ and antibody $(\mathrm{Ab})$ beta cells with are marked with brown cells. In the positive control group, the single test group and the combination group, seen a positive reaction of $\mathrm{Ag}$ and $\mathrm{Ab}$ insulin-producing beta-cells characterized by brown cells and insulin expression dominating pancreatic island of Langerhans.
\end{abstract}

\section{Introduction}

The type of disease that often occurs in society is diabetes mellitus (DM). DM is a chronic disease that occurs when the pancreas does not produce enough insulin or when the body cannot effectively use the insulin it produces [1]. This condition of lack of insulin will result in high blood glucose levels (hyperglycemic), where insulin will help glucose enter cells to produce energy. The International Diabetes Federation in 2013 revealed that people with DM rank 7 in Indonesia with a total of 8.5 million [2]. Hyperglycemic conditions result in increased production of reactive compounds through nonenzymatic glycation pathways on proteins, polyol-sorbitol pathways, and glucose autoxidation [3], excessive reactive compounds will cause an imbalance of endogenous antioxidants, resulting in a state of oxidative stress. Oxidative stress plays an important role in the complications of DM, where the state of oxidative stress occurs due to an imbalance between free radicals and natural antioxidants [4], [5].
In this study, white rats induced intraperitionally with streptozotocin-nicotinamide (STZ-NA). Streptozotocin acts selectively on the pancreas by causing pancreatic $\beta$ cell death from the process of DNA alkylation, thereby triggering a hyperglycemic state [6]. The toxicity of STZ can be alleviated with nicotinamide by preventing the depletion of nicotinamide adenine dinucleotide in pancreatic $\beta$ cells [7].

The combination of ethanol extract of leaves of Moringa oleifera $500 \mathrm{mg} / \mathrm{kg} \mathrm{BW}$ and free Ocimum leaves of a maximum of $500 \mathrm{mg} / \mathrm{kg} \mathrm{BW}$ is proven to normalize fasting blood glucose levels and improves testicular structure and spermatogenesis in sexual dysfunction caused by diabetes [8]. Clove fruit powder at a dose of $1000 \mathrm{mg} / \mathrm{kg} \mathrm{BW}$ shows an increase in levels of antioxidant enzymes (superoxide dismutase [SOD], glutathione peroxidase [GPx], catalase [CAT], and glutathione-S-transferase) in overcoming oxidative stress conditions and can act to reduce lipid levels under high-fat diet conditions [9]. The combination of Moringa oleifera leaf extract and Syzygium aromaticum flower extract has the activity to reduce blood glucose 
levels, with the best antidiabetic activity, namely the combination of moringa and clove extracts dose of $150: 40 \mathrm{mg} / \mathrm{kg} \mathrm{BW}$ in DM rats induced by STZ-NA [8].

Based on previous research, this can be a reference because it is known that the two Simplicia have a chemical content in them that has the potential to repair pancreatic beta cells which can be seen in decreasing blood glucose levels of the tested animals. The use of the two simplicia as a herbal combination is expected to increase the regeneration of pancreatic beta cells so as to stimulate insulin release. The parameters to be tested were the histopathological regeneration of pancreatic beta cells in rats. For this reason, the problem can be raised whether the combination of ethanol extract of clove flowers and ethanol extract of moringa leaves can increase pancreatic regeneration in streptozotocin-nicotinamide-induced rats through the histopathological method of hematoxylin-eosin (HE) and immunohistochemical (IHC) staining. Therefore, the aim of this study was to prove the presence of pancreatic regeneration activity in the combination of ethanol extract of clove flower and ethanol extract of moringa leaves to streptozotocin-nicotinamide-induced rats through the histopathological method of $\mathrm{HE}$ and $\mathrm{IHC}$ staining.

\section{Materials and Methods}

\section{Grouping of animals test}

Table 1.

Grouping of animals test can be seen in

Rats having blood glucose levels $\geq 126 \mathrm{mg} / \mathrm{dL}$ were used in the study. Furthermore, in groups I to VIII, rats were given treatment in the form of glibenclamide, $\mathrm{Na}-\mathrm{CMC}$, and a combination preparation of clove flower and moringa leaf ethanol extract for 28 days with a duration of once a day. Then, on the $29^{\text {th }}$ day, the rats

Table 1: Grouping of animals test

\begin{tabular}{|c|c|c|}
\hline Group & $\begin{array}{l}\text { Number } \\
\text { of Mice }\end{array}$ & Treatment \\
\hline $\begin{array}{l}\text { I (normal } \\
\text { control) }\end{array}$ & 5 & Na-CMC $1 \%$ suspension solution \\
\hline $\begin{array}{l}\text { II (positive } \\
\text { control) }\end{array}$ & 5 & $\begin{array}{l}\text { Rats induced by STZ } 60 \mathrm{mg} / \mathrm{kg} \mathrm{BW-NA} 150 \mathrm{mg} / \mathrm{kg} \text { BW (I.P) } \\
\text { were given glibenclamide } 0.45 \mathrm{mg} / \mathrm{kg} \text { BW (P.O) }\end{array}$ \\
\hline $\begin{array}{l}\text { III (negative } \\
\text { control) }\end{array}$ & 5 & $\begin{array}{l}\text { Rats induced by STZ } 60 \mathrm{mg} / \mathrm{kg} \text { BW-NA } 150 \mathrm{mg} / \mathrm{kg} \mathrm{BW} \text { (I.P) } \\
\text { were given Na-CMC } 1 \% \text { (P.O) }\end{array}$ \\
\hline IV (Group I) & 5 & $\begin{array}{l}\text { Rats induced by STZ } 60 \mathrm{mg} / \mathrm{kg} \text { BW-NA } 150 \mathrm{mg} / \mathrm{kg} \mathrm{BW} \text { (I.P) were } \\
\text { given ethanol extract of moringa leaves } 100 \mathrm{mg} / \mathrm{kg} \text { BW (P.O) }\end{array}$ \\
\hline V (Group II) & 5 & $\begin{array}{l}\text { Rats induced by STZ } 60 \mathrm{mg} / \mathrm{kg} \text { BW-NA } 150 \mathrm{mg} / \mathrm{kg} \text { BW (I.P) } \\
\text { were given clove flower ethanol extract } 80 \mathrm{mg} / \mathrm{kg} \text { BW (P.O) }\end{array}$ \\
\hline VI (Group III) & 5 & $\begin{array}{l}\text { Rats induced by STZ } 60 \mathrm{mg} / \mathrm{kg} \text { BW-NA } 150 \mathrm{mg} / \mathrm{kg} \mathrm{BW}(\mathrm{I} . \mathrm{P}) \\
\text { were given a combination of ethanol extract of moringa leaves } \\
150 \mathrm{mg} / \mathrm{kg} \text { BW-ethanol extract of clove flower } 40 \mathrm{mg} / \mathrm{kg} \\
\text { BW (P.O) }\end{array}$ \\
\hline $\begin{array}{l}\text { VII (Group } \\
\text { IV) }\end{array}$ & 5 & $\begin{array}{l}\text { Rats induced by STZ } 60 \mathrm{mg} / \mathrm{kg} \text { BW-NA } 150 \mathrm{mg} / \mathrm{kg} \mathrm{BW} \text { (I.P) } \\
\text { were given a combination of moringa leaf ethanol extract } 100 \\
\mathrm{mg} / \mathrm{kg} \text { BW-ethanol extract of clove flower } 80 \mathrm{mg} / \mathrm{kg} \text { BW (P.O) }\end{array}$ \\
\hline $\begin{array}{l}\text { VIII (Group } \\
\text { V) }\end{array}$ & 5 & $\begin{array}{l}\text { Rats induced by STZ } 60 \mathrm{mg} / \mathrm{kg} \text { BW-NA } 150 \mathrm{mg} / \mathrm{kg} \mathrm{BW} \text { (I.P) } \\
\text { were given a combination of ethanol extract of moringa leaves } \\
50 \mathrm{mg} / \mathrm{kg} \text { BW-ethanol extract of clove flower } 120 \mathrm{mg} / \mathrm{kg} \\
\text { BW (P.O) }\end{array}$ \\
\hline
\end{tabular}

were then necropsied and the pancreatic preparations were observed.

\section{Histopathological test procedure}

The experimental animal was sacrificed under anesthesia, then all parts of the pancreas were taken. Then, the pancreatic tissue is made in histopathological preparations as follows.

First, tissue fixation is performed.

Second, tissue dehydration.

Third, clearing the tissues.

Fourth, making paraffin blocks.

Fifth, slicing the tissues.

Sixth, deparaffinization and dehydration.

Seventh, tissues staining.

Eighth, tissues observation was followed by IHC methods.

The order of preparation and staining of rat pancreatic tissue

1. Pancreatic tissue sample slide preparation

2. Cutting the tissue using paraffin

3. IHC staining

4. Quantification of $\beta$ cell expression to insulin (using the MacBiophotonics Image J program).

\section{Results and Discussion}

\section{Results of observation of rats pancreas organ with HE and IHC staining}

The results ofHE staining on pieces of pancreatic tissue in all groups were evaluated by looking at the morphology of the pancreatic islets of Langerhans $\beta$. HE staining was carried out to qualitatively see the general morphology of the pancreatic tissue of the treated rats. This staining consists of two color components, namely $\mathrm{HE}$. Hematoxylin is alkaline dyes that can color acidic cell nuclei, while eosin is an acidic dye so that it can color the cytoplasm which is alkaline [10]. The observed parameter of HE staining on pancreatic preparations was the general morphology of pancreatic tissue. The following Figure 1 are the results of HE staining photos of pieces of rats pancreatic tissue.

About $65 \%$ of all cells in the islet of Langerhans pancreas are $ß$ cells, which play a role in secreting insulin. Pancreatic $B$ cells are the cells most sensitive to the presence of glucose in the blood. In diabetes, there will be morphological changes in $B$ cells, both in size and number. Therefore, the number of $\beta$ cells in Langerhans Islands is an important parameter to determine the level of pancreatic damage [11]

The histopathological changes of islets of Langerhans in diabetics have been reported by a 


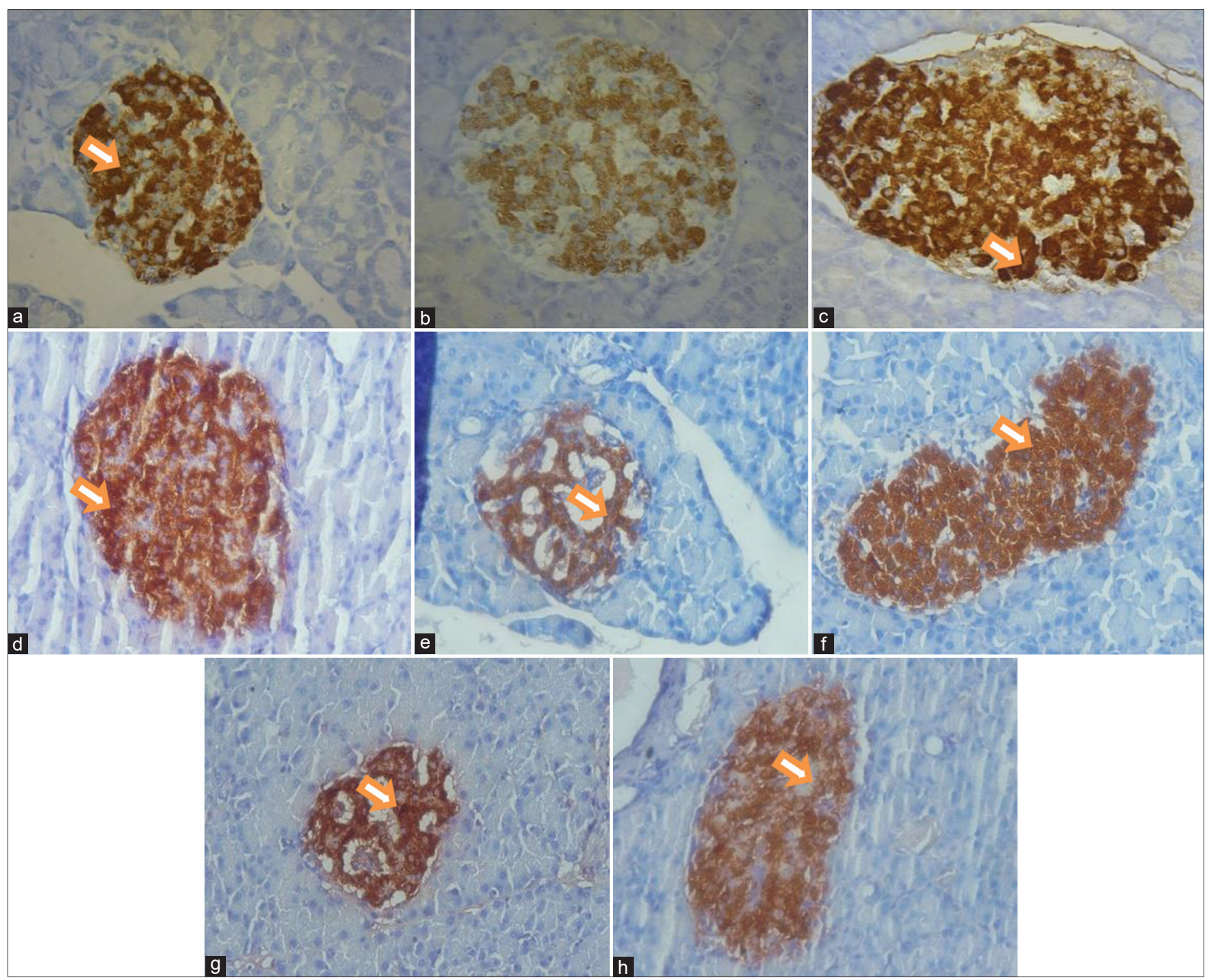

Figure 1: The results of the islet cells of the pancreas with IHC staining with a magnification of $40 \times$ (a) Normal rat islet cells of Langerhans Island. Positive reactions of $\mathrm{Ag}$ and $\mathrm{Ab}$ are indicated by a brown color. Normal islet cell population. (b) Islet cells of Langerhans Island of negative control. The negative reactions of $\mathrm{Ag}$ and $\mathrm{Ab}$ are characterized by a lack of brown islet cells. The cells undergo necrosis. (c) Islet cells of Langerhans Island of positive control. (d) Islet cells of Langerhans Island in the moringa extract test group at a dose of $100 \mathrm{mg} / \mathrm{kg}$ BW. (e) Islet cells of Langerhans Island in the clove extract test group at a dose of $80 \mathrm{mg} / \mathrm{kg} B W$. (f) Islet cells of Langerhans Island in the test group for the combination of moringa and clove extracts at a dose of 150:40 mg/kg BW. (g) Islet cells of Langerhans Island in the combination test group of moringa and clove extracts at a dose of 100:80 mg/kg BW. (h) Islet cells of Langerhans Island test group of the combination of moringa and clove extracts at a dose of 50:120 mg/kg bb positive reactions of $\mathrm{Ag}$ and $\mathrm{Ab}$ are marked with brown color

number of investigators. These changes can occur either quantitatively, such as a reduction in number or size, or qualitatively, such as necrosis and degeneration. Damage to pancreatic beta cells can be caused by many factors. These factors include genetic factors, infection by germs, nutritional factors, diabetogenic substances, and free radicals (oxidative stress) [12]. In the results of the HE photo of the negative control group, the morphological condition of Langerhans Islands was reduced and necrosis occurred, this was due to the destruction of pancreatic $\beta$ cells due to the toxicity of streptozotocin so that cells could experience necrosis [13]. Damage to pancreatic $\beta$ cells causes the body to not produce insulin, causing hyperglycemia. Hyperglycemic conditions can result in the formation of reactive oxygen species (ROS). An increase in ROS that is not balanced with an increase in endogenous antioxidant enzymes such as SOD and GPx as a body defense mechanism can cause oxidative stress and can exacerbate damage to pancreatic $\beta$ cells.

In the HE photo of the positive control group, the single test group and the combination of the ethanol extract of moringa leaves and clove flowers, the islet cells of Langerhans Island were larger than the negative control group. The morphology of the islet of Langerhans, which is getting bigger, indicates increased regeneration of the pancreatic $\beta$ islet cells.

In IHC observations, the parameters used in this study were insulin expression which is immunoreactive against insulin in the pancreas. Immunohistochemistry is a technique for detecting the presence of various components contained in cells 
and tissues using the principle of the antigen $(\mathrm{Ag})$ and antibody $(\mathrm{Ab})$ bond reactions. Giving STZ-NA induction triggers damage in pancreatic $\beta$ cells and significantly affects insulin expression. However, insulin expression increased gradually in the group of mice that were given therapeutic treatment for 28 days.

Observations with IHC staining techniques can be seen in the distribution of $\beta$ cells that produce insulin in the islets of Langerhans which are shown in brown cells. Langerhans Island is dominated by $\beta$ cells. Following are the results of $\mathrm{IHC}$ photos of pieces of mouse pancreatic tissue.

Based on Figure 2, the results obtained in each treatment group gave different results for insulin expression in each treatment group. The normal group shows a picture of normal or healthy conditions from Langerhans Island, which is also supported by the IHC image of Langerhans islet cells where the number of islet cells dominates the Langerhans Island (Figure 2).

In the IHC results of the negative control group (Figure 2), there is a lack of intensity in the display of positive reactions of $\mathrm{Ag}$ and $\mathrm{Ab} \beta$ cells which are marked by brown cells. In the IHC photo data from the positive control group, the moringa extract group, clove extract, combination I, II, and III extract doses (Figure 2) show a positive reaction of $\mathrm{Ag}$ and $\mathrm{Ab}$ insulin-producing $\beta$ cells which are marked by brown cells and expression insulin which dominates the islets of Langerhans.

Analysis of the percentage expression of Langerhans $\beta$ cells that are immunoreactive to insulin was obtained through the results of a semiquantitative
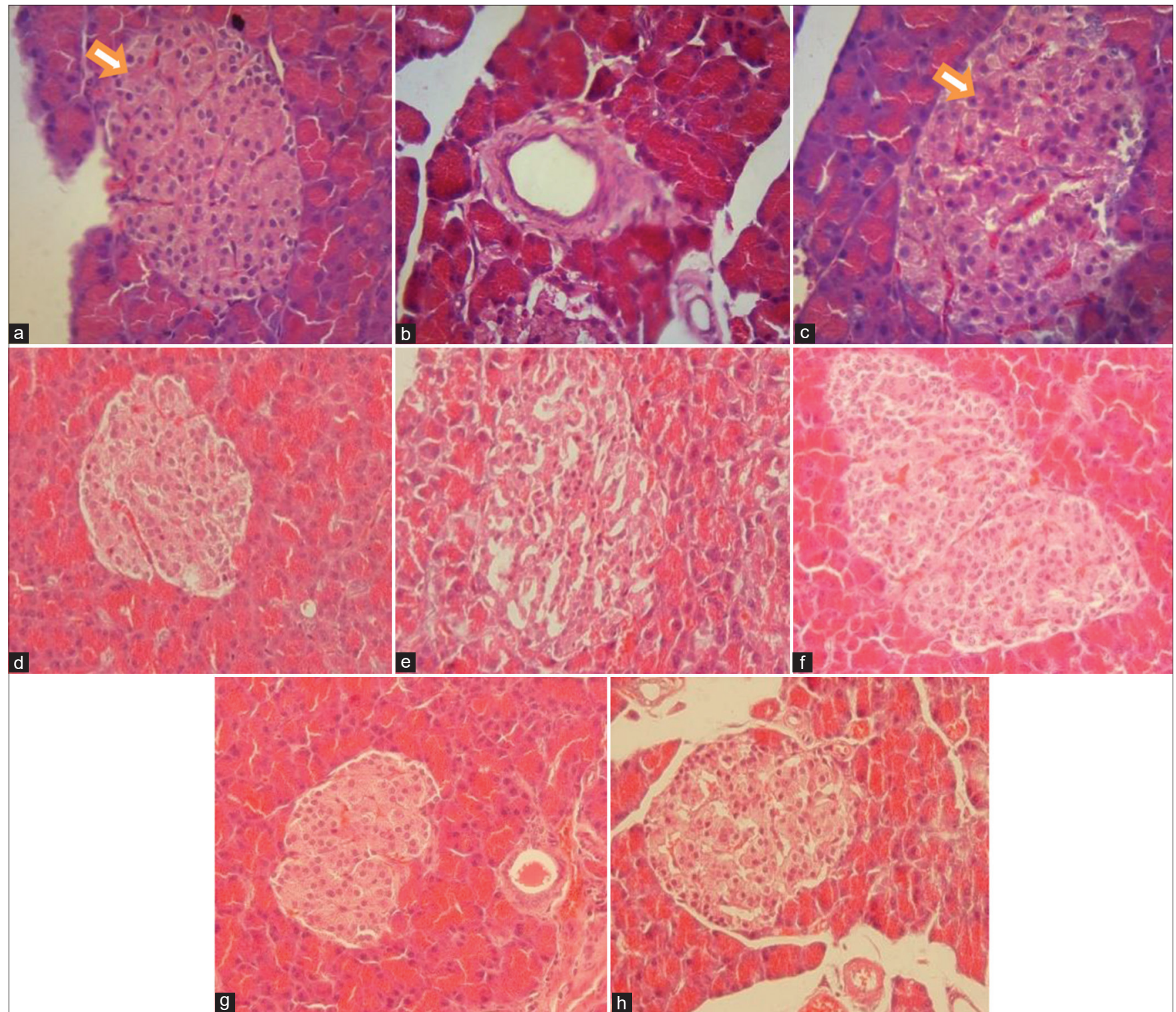

Figure 2: Results of photos of Langerhans Islands, pieces of the pancreas with hematoxylin-eosin staining with a magnification of 40x (a) Langerhans Island of normal rat. (b) Langerhans Island of negative control. The cells undergo necrosis so that the islets of Langerhans appear to be shrunken. (c) Langerhans Island of positive control. (d) Langerhans Island, moringa extract test group $100 \mathrm{mg} / \mathrm{kg}$ BW. (e) Langerhans Island, clove extract test group $80 \mathrm{mg} / \mathrm{kg} \mathrm{BW}$. (f) Langerhans Island combination test group I moringa clove 150: $40 \mathrm{mg} / \mathrm{kg}$ BW. (g) Langerhans Island combination test group II moringa clove 100: $80 \mathrm{mg} / \mathrm{kg} \mathrm{BW}$. (h) Langerhans Island group III combination test of moringa clove $50: 120 \mathrm{mg} / \mathrm{kg} B W$ 
analysis of the MacBiophotonics Image $\mathrm{J}$ program, where these results will show the extent and intensity of the color of the bonds that occur. The results are then calculated the average so that the percentage is obtained as in Table 2.

Table 2: The average results of the calculation of insulin immunoreactivity in the pancreas of rats with IHC staining

\begin{tabular}{ll}
\hline Treatment group & Insulin immunoreactivity rate (\%) \\
\hline I & $63.56 \pm 5.69$ \\
II & $41.30 \pm 5.34$ \\
III & $61.86 \pm 2.69$ \\
IV & $54.23 \pm 5.55$ \\
V & $54.39 \pm 14.82$ \\
VI & $57.51 \pm 14.72$ \\
VII & $56.71 \pm 11.40$ \\
VIII & $53.66 \pm 7.41$ \\
\hline Information: & \\
I=Normal group & \\
II=Negative control group & \\
III=Positive control group & \\
IV=Moringa extract group at a dose of $100 \mathrm{mg} / \mathrm{kg}$ BW & \\
V=Clove extract group dose $80 \mathrm{mg} / \mathrm{kg}$ BW & \\
VI=Combination group of moringa and cloves, dose $150: 40 \mathrm{mg} / \mathrm{kg}$ body weight \\
VII=Combination group of moringa and cloves dose $100: 80 \mathrm{mg} / \mathrm{kg} \mathrm{BW}$ \\
VIII=Combination group of moringa and clove dose $50: 120 \mathrm{mg} / \mathrm{kg}$ BW.
\end{tabular}

Based on Table 2, the results of IHC photo acquisition and $\beta$ cell expression after treatment in each therapy group increased. This shows that there was a decrease in cell damage and the activity of $\beta$ cell expression which began to improve after giving therapy. In the positive control group (Glibenclamide), it is suspected that homeostatic restoration of blood glucose levels can occur so that it can reduce oxidative damage due to high blood glucose levels so that endogenous antioxidants can work properly to neutralize reactive compounds. The single and combined dose extract therapy groups are thought to work as strong antioxidant substances/ingredients, so they can neutralize excess reactive compounds in diabetes. Apart from working as an antioxidant, single and combined dose extract therapy groups are also thought to play a role in insulin secretion, inhibition of liver glucose synthesis, inhibit postprandial glucose absorption, and protect pancreatic tissue from oxidative stress [14], [15], [16].

From the results obtained, the negative control group analysis had the effect of the weakest $\beta$ cell expression. Decreased expression of pancreatic Langerhans $\beta$ cells indicates reduced insulin synthesis by these cells so that administration of antibodies to insulin (IHC staining) only reacts with cells that still produce insulin. Decreased insulin synthesis indicates damage to pancreatic Langerhans cells by induction of STZ. STZ is toxic by causing damage to cell DNA; in the cell, streptozotocin is similar to glucose transported by the glucose transport protein, GLUT2, but is not recognized by other glucose transport proteins that cause alkylation. Streptozotocin works by forming highly reactive free radicals that can cause damage to cell membranes, proteins, and DNA, causing disruption of insulin production by pancreatic Langerhans beta cells [17], [18], [19].

The results of the observation that the combination test groups I, II, and III contain compounds that have the potential to improve glucose homeostasis which is disturbed by the inducing agent.
Giving therapy for 28 days is considered capable of reducing blood glucose levels and begins to show a restoration of the expression of pancreatic $\beta$ cells which are immunoreactive to insulin. In general, the combination I (moringa extract and cloves dosage $150: 40 \mathrm{mg} / \mathrm{kg} \mathrm{BW}$ ) gave the best results with a higher reduction in blood glucose levels than the single-dose test preparation and other combinations. This shows that giving a combined test dosage of moringa and clove extracts at a dose of $150: 40 \mathrm{mg} / \mathrm{kg} \mathrm{BW}$ in a relatively long period of time (28 days) can inhibit the rate of pancreatic damage and regenerate pancreatic $\beta$ cells. Thus, it can increase the working sensitivity of pancreatic $\beta$ cells to produce insulin and can restore the work of pancreatic $\beta$ cells to normal. It is known that pancreatic Langerhans $\beta$ cells are a group of stable cells that are able to proliferate throughout their life so that pancreatic Langerhans beta cells can synthesize insulin again [20].

Based on the results of TLC, it was found that the content of compounds in moringa and clove extracts, namely flavonoids, alkaloids, saponins, and tannins which based on previous studies, was reported to act as an antidiabetic because in this study, it was proven that blood glucose levels began to improve and began to show recovery of $\beta$ cell expression. The pancreas so that it can synthesize insulin again. According to the antioxidants contained in $M$. oleifera include Vitamin $C$ and flavonoids so that Moringa leaves have a strong activity as an oxidant scavenger that can inhibit ROS reactions and increase SOD, GSH, and CAT activity which causes a decrease in oxidative stress [21]. In the cell-based on research, it is stated that the chemical content in S. aromaticum such as eugenol and oleanolic acid can act as the main antioxidant and scavenger in warding off free radicals [22].

\section{Conclusions}

Tissue staining and observation of liver tissue using the HE method obtained a positive control group, a single test group and a combination seen islet cells on the island of Langerhans pancreas greater than the negative control group. The morphology of the island of Langerhans that is getting bigger indicates increased regeneration of pancreatic beta islet cells.

In the IHC method, the negative control group showed a lack of intensity in the display of positive reactions of $\mathrm{Ag}$ and $\mathrm{Ab}$ beta cells which were marked with brown cells. In the positive control group, single and combination test groups, it was seen that there was a positive appearance of $\mathrm{Ag}$ and $\mathrm{Ab}$ insulin-producing beta-cells characterized by brown cells and insulin expression that dominated the pancreatic islets of Langerhans. 


\section{References}

1. Harikumar K, Kumar BK, Hemalatha GJ, Kumar MB, Lado F. A review on diabetes mellitus. Int $\mathrm{J}$ Novel Trends Pharm Sci. 2015;5(3):201-17.

2. IDF Clinical Guidelines Task Force. Global guideline for Type 2 diabetes: Recommendations for standard, comprehensive and minimal care. Diabet Med. 2006;23(6):579-93. https://doi. org/10.1111/j.1464-5491.2006.01918.x

PMid:16759299

3. Setiawan B, Suhartono E. Oxidative stress and the role of antioxidants in diabetes mellitus. Majalah Kedokteran Indones. 2005;55(2):1-37.

4. Giacco F Brownlee M. Oxidative stress and diabetic complications. Circ Res. 2010;107(9):1058-70. https://doi. org/10.1161/circresaha.110.223545

PMid:21030723

5. Esteghamati A, Eskandari D, Mirmiranpour H, Noshad S, Mousavizadeh M, Hedayati M, Nakhjavani M. Effects of metformin on markers of oxidative stress and antioxidant reserve in patients with newly diagnosed type 2 diabetes: A randomized clinical trial. Clin Nutr. 2013;32(2):179-85. https:// doi.org/10.1016/j.clnu.2012.08.006

\section{PMid:22963881}

6. Lenzen S. The mechanisms of alloxan and streptozotocininduced diabetes. Diabetologia. 2008;51(2):216-26. https://doi. org/10.1007/s00125-007-0886-7

PMid: 18087688

7. Tahara A, Matsuyama-Yokono A, Nakano R, Someya $Y$ Shibasaki M. Hypoglycaemic effects of antidiabetic drugs in streptozotocin-nicotinamide-induced mildly diabetic and streptozotocin-induced severely diabetic rats. Basic Clin Pharmacol Toxicol. 2008;103(6):560-8. https://doi. org/10.1111/j.1742-7843.2008.00321.x PMid: 18793271

8. Hardani MF, Hardani R, Rahmawati S, Hamzah B. Endogenous antioxidant activity combination of moringa leaf and clove flower extracts toward diabetic rats (Rattus norvegicus). Eur J Mol Clin Med 2020;7(10):1806-13.

9. Shyamala MP, Venukumar MR, Latha MS. Antioxidant Potential of the Syzygium aromaticum L. (Cloves) in rats fed with high fat diet. Indian J Pharmacol. 2003;35(2):99-103.

10. Bacha WJ Jr., Wood LM. Color Atlas of Veterinary Histology. $3^{\text {nd }}$ ed. London, United Kingdom: Lippincot Williams \& Wilkins; 2012.

11. Deng SM, Vatamanjuk X, Huang N, Doliba MM, Lian NA, FrankE, et al. Structural and functional abnormalities in the islets isolated from Type 2 diabetic subjects. Diabetes. 2004;53(3):624-32. https://doi.org/10.2337/diabetes.53.3.624

\section{PMid:14988246}

12. Suarsana IN, Priosoeryanto BP, Bintang M, Wresdiyati T. Blood glucose profile and ultrastructure of rat pancreatic beta cells induced by alloxan compounds. JITV. 2010;15(2):118-23.

13. SzkudelskiT. The mechanism of alloxan and streptozotocin action in B cells of the rat pancreas. Physiol Res. 2001;50(6):536-54.

PMid:11829314

14. Gupta R, Mathur M, Bajaj VK, Katariya P, Yadav S, Kamal R, Gupta RS. Evaluation of antidiabetic and antioxidant activity of Moringaoleiferainexperimentaldiabetes.JDiabetes.2012;4(2):16471. https://doi.org/10.1111/j.1753-0407.2011.00173.x PMid:22103446

15. Khathi A, Serumula MR, Myburg RB, van Heerden FR, Musabayane CT. Effects of Syzygium aromaticum-derived triterpenes on postprandial blood glucose in streptozotocininduced diabetic rats following carbohydrate challenge. PLoS One. 2013;8(11):e81632. https://doi.org/10.1371/journal. pone.0081632 PMid:24278452

16. Prasad RC, Herzog B, Boone B, Sims L, Law MW. An extract of Syzygium aromaticum represses genes encoding hepatic gluconeogenic enzymes. J Ethnopharmacol. 2005;96(1-2):295301. https://doi.org/10.1016/j.jep.2004.09.024 PMid:15588682

17. Skovso S. Modeling Type 2 diabetes in rats using high fat diet and streptozotocin. J Diabetes Investig. 2014;5(4):349-58. https://doi.org/10.1111/jdi.12235 PMid:25411593

18. Panchal SK, Poudyal H, lyer A, Nazer R, Alam MA, Diwan V, et al. High-carbohydrate, high-fat diet-induced metabolic syndrome and cardiovascular remodeling in rats. $\mathrm{J}$ Cardiovasc Pharmacol. 2011;57(5):611-24. https://doi.org/10.1097/ fjc.0b013e3181feb90a PMid:21572266

19. Zalukhu ML, Phyma AR, Pinzon RT. Aging process, oxidative stress, and the role of antioxidants. CDK. 2016;43(10):733-6.

20. McGavin MD, Zachary JF. Pathology Basis of Veterinary Disease. $4^{\text {th }}$ ed. St. Louis: Academic Press, Elsevier; 2007.

21. Shih MC, Chang CM, Kang SM, Tsai ML. Effect of different parts (leaf, stem and stalk) and seasons (summer and winter) on the chemical compositions and antioxidant activity of Moringa oleifera. Int J Mol Sci. 2011;12(9):6077-88. https://doi. org/10.3390/ijms12096077

PMid:22016645

22. Musabayane $C$, Tufts $M$, Mapanga $R$. Synergistic antihyperglycemic effects between plant-derived oleanolic acid and insulin in streptozotocin-induced diabetic rats. Ren Fail. 2010;32(7):832-9. https://doi.org/10.3109/08860 22x.2010.494802

PMid:20662697 